\title{
A new species of Wallinia Pearse, 1920 (Digenea: Allocreadiidae) in Astyanax mexicanus (Characidae) from Mexico revealed by morphology and sequences of the $28 \mathrm{~S}$ ribosomal RNA gene
}

\author{
Gerardo Pérez-Ponce de León ${ }^{1}$, Ulises Razo-Mendivil ${ }^{2}$, Berenit Mendoza-Garfias ${ }^{1}$, Miguel Rubio-Godoy ${ }^{2}$ and \\ Anindo Choudhury ${ }^{3}$
}

\author{
${ }^{1}$ Laboratorio de Helmintología, Instituto de Biología, Universidad Nacional Autónoma de México, México, D.F., Mexico; \\ ${ }^{2}$ Instituto de Ecología, Red de Biología Evolutiva, Xalapa, Veracruz, Mexico; \\ ${ }^{3}$ Division of Natural Sciences, St. Norbert College, De Pere, Wisconsin, USA
}

\begin{abstract}
Wallinia mexicana sp. n. is described from the Mexican tetra, Astyanax mexicanus (De Filippi) (Characidae Weitzman), from two localities in northern Mexico. The new species can be distinguished from the two congeneric species, described from small-bodied characids in South and Central America, mainly by the posterior extent of the vitelline follicles (halfway between the posterior testis and the end of the caeca), by having a larger oesophagus, testes that are always oblique, and eye-spot remnants. The distinct status of the new species was confirmed by molecular data (28S rRNA gene sequences). Phylogenetic analysis suggests the new species is the sister species of W. chavarriae Choudhury, Hartvigsen et Brooks, 2002 described from characids in northwestern Costa Rica. Additionally, genetic divergence between these congeners reached 3.3\%, a value higher than that observed for closely related species pairs of allocreadiids for that molecular marker. Based on these new findings, recently published records of this new species as Magnivitellinum simplex Kloss, 1966 and Creptotrematina aguirrepequenoi Jiménez-Guzmán, 1973 in Astyanax mexicanus from Durango and San Luis Potosi states, respectively, are corrected.
\end{abstract}

Keywords: taxonomy, DNA, helminths, freshwater fish, North America

Within Characiformes, a widespread tropical order of ostariophysan fishes, the family Characidae Weitzman is the most diverse among Neotropical fishes, with approximately 1200 species (Mirande 2010). Within this family, the genus Astyanax Baird et Girard comprises the most diverse assemblage of more than 107 recognised species (Ornelas-García et al. 2008). In Mexico, nearly 41 helminth species have been recorded in five of the eight species of characids currently distributed there (PérezPonce de León and Choudhury 2010), and new host and distributional records, and even new species of helminths, continue to be reported on a regular basis (e.g. Mendoza-Franco et al. 2013, Pérez-Ponce de León et al. 2013, Aguilar-Aguilar et al. 2014, Razo-Mendivil et al. 2014a).

Since characids are essentially Neotropical, phylogenetic analyses of members of their core helminth parasite fauna (sensu Pérez-Ponce de León and Choudhury 2005) are prime targets to help clarify patterns and processes that have shaped host associations and biogeography, and particularly for an analysis of host-switching and vicariance as mediators of diversification (Choudhury et al. 2002). However, the diversity of the helminth parasite fauna in this host group needs to be well documented and the use of a DNA-taxonomy approach has shown that not all the species have been described yet.

During investigations on the helminth fauna of fishes in river drainages of northern Mexico, two species of allocreadiids were reported from the Mexican tetra, Astyanax mexicanus (De Filippi), namely Magnivitellum simplex Kloss, 1966 and Creptotrematina aguirrepequenoi Jiménez-Guzmán, 1973 (see Pérez-Ponce de León et al. 2010, 2013). We recently sequenced the D1-D3 domains of the 28S rRNA gene of specimens from that study and, on comparing sequences with those available for $M$. simplex, C. aguirrepequenoi and another closely similar allocreadiid, Wallinia chavarriae Choudhury, Hartvigsen et Brooks, 2002, realised that the aforementioned records of $M$. simplex and C. aquirrepequenoi may be in error. Reexamination of specimens from the original studies confirmed that the records were of a previously undescribed 
species of Wallinia Pearse, 1920. Here we use morphological and molecular data to argue for the recognition of a new species of Wallinia.

\section{MATERIALS AND METHODS}

Species previously reported as Magnivitellinum simplex were collected from Astyanax mexicanus in the Río Covadonga, in Peñon Blanco, Durango State, in 2008. These specimens were deposited in the Colección Nacional de Helmintos, Instituto de Biología, the Colección Nacional de Helmintos, Mexico City, Mexico (CNHE), under accession numbers CNHE 6311-6313. Prevalence and mean intensity of infection were $50 \%$ (2/4) and 5.5 digeneans per infected host, respectively. Two specimens were fixed in $99 \%$ ethanol for DNA extraction. Meanwhile, specimens identified as Creptotrematina aguirrepequenoi at the time were collected from A. mexicanus in the Río Huichihuayán, San Luis Potosí State, in 2009 and were deposited at the CNHE under accession number CNHE 7411. Prevalence and mean intensity of infection were $21 \%(4 / 19)$ and 1.8 digeneans per infected host, respectively. One specimen was fixed in $99 \%$ ethanol for DNA extraction.

Specimens intended for morphological study were fixed with hot (steaming) 4\% formalin, stained with Gomori's trichrome, Delafield's haematoxylin,or Mayer's paracarmine, dehydrated in a graded ethanol series, cleared in methyl salicylate and mounted as permanent slides using Canada balsam. Specimens are deposited in CNHE, Universidad Nacional Autónoma de México (UNAM), one specimen is deposited in the helminthological collection of the Institute of Parasitology, BC ASCR, České Budějovice, Czech Republic (IPCAS D-710). Measurements are in micrometres, unless otherwise stated, with the range followed by the mean in parentheses. Drawings were made with the aid of a drawing tube attached to an Olympus BX51 microscope.

For morphological comparisons, museum specimens were examined as follows. From the CNHE: Creptotrematina aguirrepequenoi ex Astyanax mexicanus, Cuatro Ciénegas, Coahuila (CNHE 8416); Magnivitellinum simplex ex Astyanax aeneus (Gunther), Río Ayuquila (CNHE 4787), ex A. mexicanus, Río Acamulco, Pánuco (CNHE 4840), ex A. fasciatus (Cuvier) (= A. aeneus), Cenote Dos Bocas, Quintana Roo (CNHE 2684), ex Ariopsis felis (Linnaeus), Ramonal in Rio Hondo, Quintana Roo (CNHE 2846), ex A. fasciatus (= A. aeneus), Torsuani, Nicaragua (CNHE 4195). From the Smithsonian National Museum of Natural History (NMNH), Washington, D.C. (formerly United States National Parasite Collection - USNPC): Wallinia valenciae Pearse 1920, ex Geophyrocharax valenciae Eigenmann, Lake Valencia, Venezuela (USNPC 7569) (holotype); Wallinia chavarriae ex Bryconamericanus sceloparius Regan, Quebrada Limonal, Guanacaste, Costa Rica (USNPC 91364, holotype), ex A. aeneus, Río Sapoa, Guanacaste, Costa Rica (USNPC 91635-91638), and Harold W. Manter Laboratory of Parasitology, Lincoln, Nebraska (HWML 16431-16433).

Methods used for DNA extraction, PCR amplification, sequencing, phylogenetic analyses and sequence divergence values follow those recently described by Razo-Mendivil et al. (2014a). Sequences generated in this study were deposited in the GenBank database under accession numbers KJ535504-KJ535505. Sequences of the 28S rRNA gene of the new species of Wallinia were compared with sequences recently analysed by Razo-Men- divil et al. (2014a) for testing the phylogenetic position of the sequenced specimens within the Allocreadiidae Looss, 1902, and for obtaining genetic divergence values through uncorrected ' $p$ ' distances.

\section{RESULTS}

Wallinia mexicana sp. n.

Figs. 1-5

ZooBank number for species:

urn:1sid:zoobank.org:act:9A6982BC-B23F-

4B77-8ED1-360C8F8B7CCA

Description (based on 12 whole-mounted specimens): Allocreadiidae. Body 2.52-3.42 mm (2.88 mm) long, with maximum width 608-879 (730) in post-testicular region where caeca end; anterior extremity bluntly rounded. Remnants of eye-spots present at level of pharynx. Oral sucker 213-308 (254) long, 255-333 (290) wide. Ventral sucker 231-315 (272) long, 242-312 (285) wide; opening ovoid or rounded. Ratio of oral sucker length to ventral sucker length $1: 0.76-1.21$ (1:0.93); ratio of oral sucker width to ventral sucker width $1: 0.88-1.35$ (1: 1.02). Prepharynx lacking. Pharynx muscular, 92-129 (115) long, 106-156 (135) wide. Oesophagus narrow, relatively long, 114-285 (193). Cluster of gland-cells situated laterally on either side of pharynx and oesophagus, clearly visible in specimens stained with Gomori's trichrome. Caecal bifurcation short distance anterior to ventral sucker, 435-512 (496) from anterior end of body; caeca terminate blindly halfway between posterior testis and posterior end of body, at 458-818 (659) from posterior end; left or right caecum occasionally longer.

Testes two, always oblique, rounded or ellipsoidal, smooth; anterior testis 197-355 (272) long, 161-232 (198) wide; posterior testis 224-380 (321) long, 154-236 (195) wide, at $864-1.25 \mathrm{~mm}(993 \mathrm{~mm})$ from posterior extremity of body; intertesticular space 188-382 (299). Cirrus-sac elongate, median, dorsal, overlapping ventral sucker and extending beyond its posterior margin, maximum width 47-82 (69, $\mathrm{n}=9)$; contains folded seminal vesicle continuous with narrower distal tubular portion, leading to indistinct, possibly ovoid pars prostatica obscured by surrounding gland-cells and distal tubular ejaculatory duct; cirrus not observed. Genital pore median, immediately posterior to caecal bifurcation.

Ovary smooth, not overlapping ventral sucker, 187-315 (243) long, 121-197 (158) wide, generally elongated or slightly triangular, with distinct distal region containing larger oocytes. Mehlis' gland comprised of scattered glandcells obscuring ootype. Seminal receptacle ovoid, 105-212 $(144, \mathrm{n}=3)$ long, 107-185 (133) wide, immediately posterior to ovary; Laurer's canal traversing dorsal side of body laterally, opens on dorsal surface just passing outer edge of caecum. Vitellarium follicular, in two ventrolateral fields extending from level of caecal bifurcation/genital pore to halfway betweeen posterior margin of posterior testis and ends of caeca; follicles overlapping caecal field ventrally; vitelline ducts unite immediately posterior to ootype to 


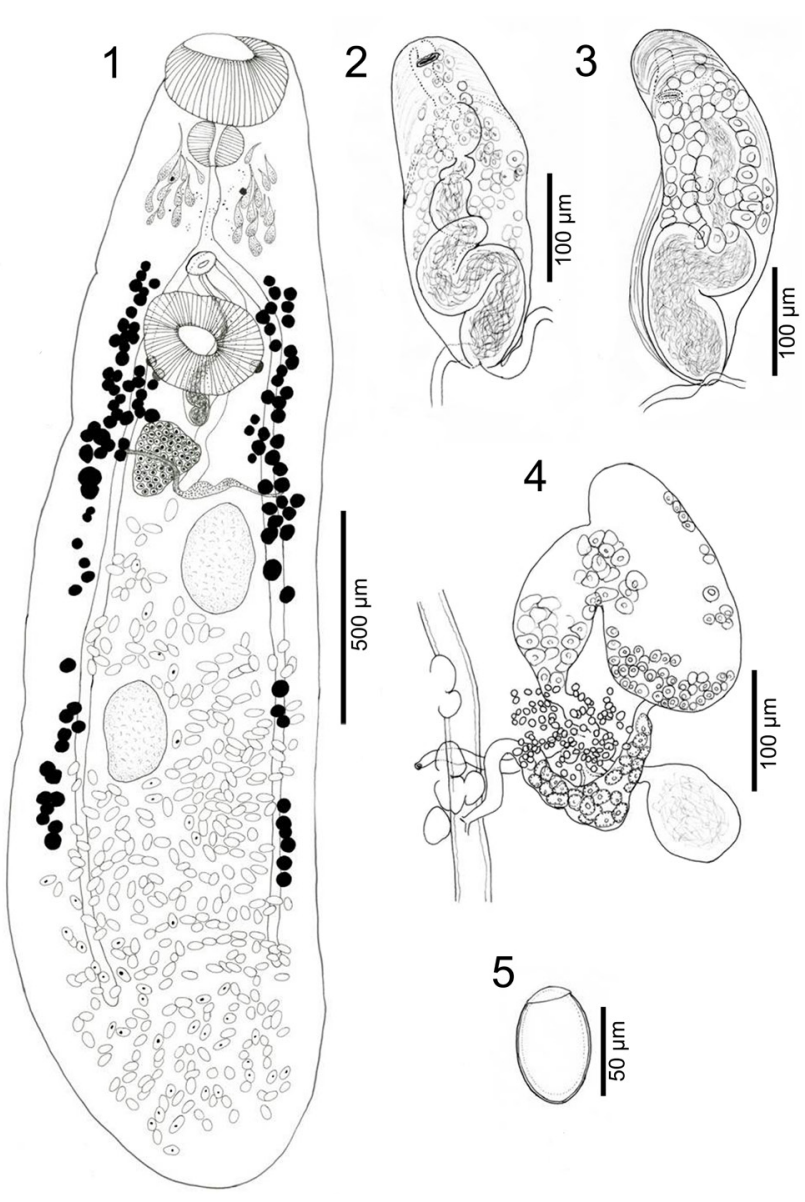

Figs. 1-5. Wallinia mexicana sp. n. from Astyanax mexicanus Fig. 1. Ventral view of whole mount (slightly flattened) specimen. Fig. 2. Ventral view of cirrus sac. Fig. 3. Dorsal view of cirrus-sac (from different specimen than in Fig. 2). Fig. 4. Female reproductive complex (with representative oocytes from different regions of the ovary). Fig 5. Operculate egg.

form vitelline reservoir. Uterus tubular, passing posteriorly between intertesticular space or alongside testes, forming convoluted loops, mostly interceacal, filling post-testicular space and extending to posterior end of body. Eggs numerous, ovoid, operculate, embryonated, 45-73 (56) long, 26-42 (32) wide $(\mathrm{n}=48)$. Excretory vesicle narrow, I-shaped, reaches level of anterior testes; excretory pore dorsoterminal.

Ty pe host: Astyanax mexicanus (De Filippi) (Actinopterygii: Characidae).

Type locality: Río Covadonga at Peñon Blanco, Durango (244ㄴ $\left.43^{\prime} 56^{\prime \prime} \mathrm{N} ; 104^{\circ} 05^{\prime} 23^{\prime \prime} \mathrm{W}\right)$.

Other localities: Río Huichihuayán, San Luis Potosí $\left(21^{\circ} 28^{\prime} 48^{\prime \prime} \mathrm{N} ; 98^{\circ} 58^{\prime} 2^{\prime \prime} \mathrm{W}\right)$.

Site of infection: Intestinal caeca, intestine

Specimens deposited: Holotype (complete wholemounted specimen, CNHE 8453); paratypes: 13 specimens from Río Covadonga (CNHE 6311-6313); 6 specimens from Río Huichihuayán (CNHE 7411); 2 paratypes at the Institute of Parasitology, BC ASCR, České Budějovice, Czech Republic (IPCAS D-710).

Etymology: The specific epithet mexicana refers to both the country and the host species (Astyanax mexicanus), where the parasite was discovered.

Remarks. Wallinia mexicana sp. n. is placed in Wallinia because it exhibits the diagnostic characters of this genus (Choudhury et al. 2002), including an unspined tegument, well-developed cirrus-sac and medium genital pore. When describing $W$. chavarriae, Choudhury et al. (2002) tentatively placed the species within the Macroderoididae McMullen, 1937. They differentiated the new species from $W$. valenciae, the type species of the genus, a parasite of Gephyrocharax valenciae in Lake Valencia, Venezuela, by using the original description (Pearse 1920), which appears to have been based on a single worm, and by examining the holotype (USNPC 7569), which is now on its side. Although comparison was difficult, $W$. chavarriae appeared to differ distinctly from $W$. valenciae in possessing a larger oral sucker (relative to the ventral sucker) and in having vitelline follicles that are rounded rather than tubular. Unfortunately, other details, such as those of the cirrus-sac and of the female reproductive complex, were either not visible or extremely difficult to discern with any degree of certainty in $W$. valenciae (see Choudhury et al. 2002).

The new species we describe herein most closely resembles $W$. chavarriae; however, it can be distinguished by having vitelline follicles extending beyond the posterior border of the posterior testis, to halfway between the posterior testis and the end of caeca, by having a larger oesophagus (193 $\mu \mathrm{m} v s 99 \mu \mathrm{m})$, distinctly oblique testes (not in tandem or slightly oblique), and by having remnants of eye-spots, or even diffuse eye-spots in some specimens (although they might have been overlooked in $W$. chavarriae). Wallinia chavarriae was described from two morphologically similar small-bodied characids, Astyanax aeneus and Bryconamericanus scleroparius, from Area Conservacion de Guanacaste, Costa Rica.

Alignment of the 28S rRNA gene consisted of 23 sequences (14 representing species of allocreadiids and eight of members of other xiphidiatan genera considered as outgroups). Alignment consisted of 1121 nucleotide positions, with 314 parsimony-informative characters. Maximum likelihood and Bayesian inference analyses recovered identical phylogenetic trees, whereas maximum parsimony recovered three equally parsimonious trees and the consensus tree showed a polytomy formed by the genera Auriculostoma Scholz, Aguirre-Macedo et Choudhury, 2004, Wallinia and Creptotrematina Yamaguti, 1953 (trees not shown). Maximum parsimony analysis recovered three equally parsimonious trees with a length of 1067 steps, a consistency index of 0.61 , and a retention index of 0.67 .

The representatives of the genus Auriculostoma were nested together with those of Wallinia and Creptotrematina (see Fig. 6) forming what Razo-Mendivil et al. (2014a) described as the characid clade for this group of allocreadiids that occur in the Neotropical biogeographical region. In that study the relationships among these allocreadiids were fully resolved, with Wallinia as the sister taxon of Creptotrematina and Auriculostoma. However, when the allocreadiid Paracreptotrema heterandriae Salgado-Maldonado, Caspeta-Mandujano et Vázquez, 2012 is included 


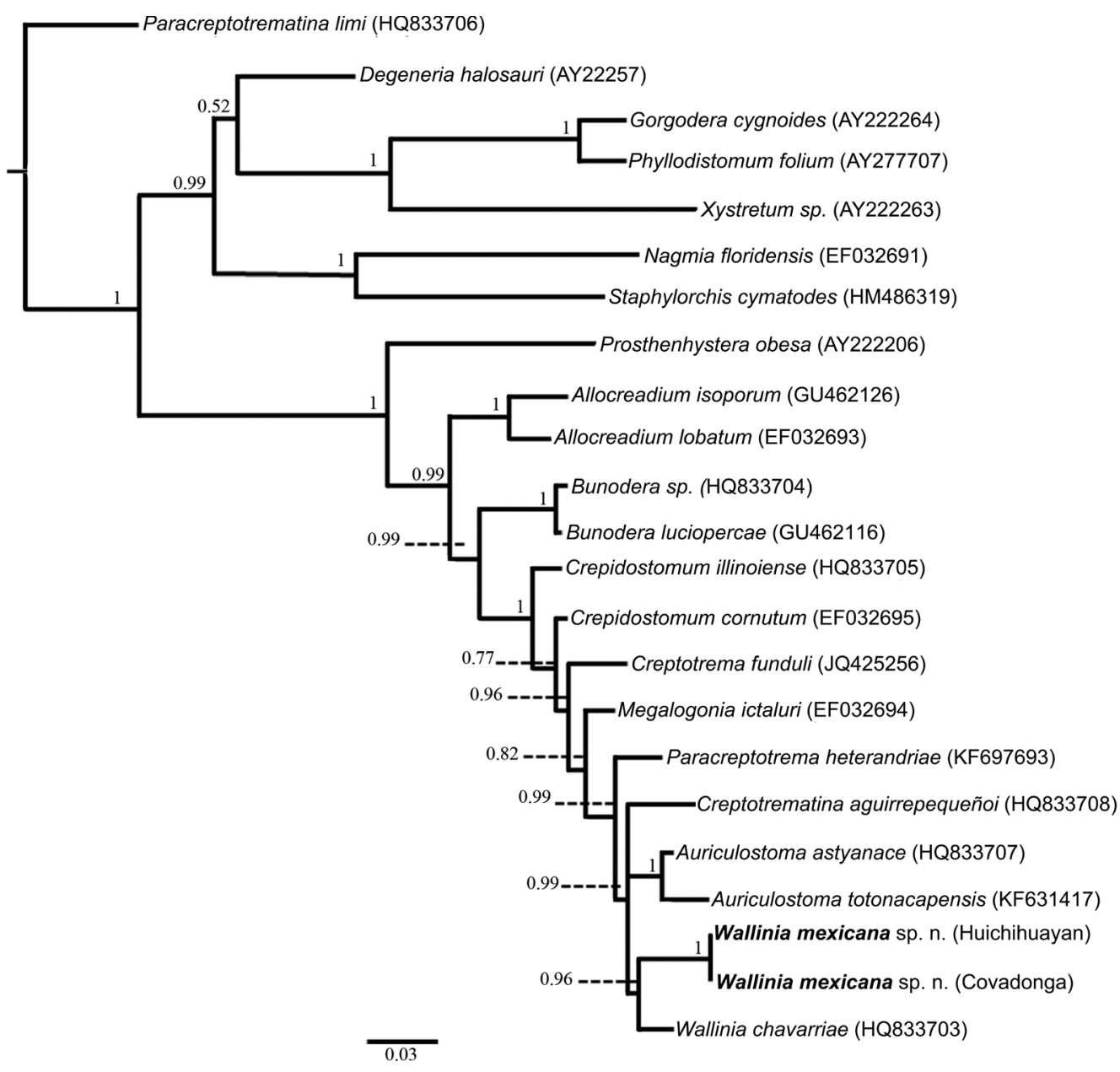

Fig. 6. Phylogenetic relationships (Bayesian inference) within the Allocreadiidae based on the 28S rRNA gene showing the position of Wallinia mexicana sp. $\mathrm{n}$. in bold. Numbers at the branches are posterior probability for Bayesian inference.

in the phylogenetic analysis of the family, sister-group relationships change (see Razo-Mendivil et al. 2014b). In our phylogenetic analysis, the topology is similar to that obtained by the aforementioned authors when $P$. heterandriae is included and Margotrema bravoae Lamothe-Argumedo, 1970 is not included. This indicates that a more thorough sampling effort is needed to accomplish a robust phylogenetic analysis of lineages within the Allocreadiidae.

No intraspecific genetic variation for the $28 \mathrm{~S}$ rRNA gene was found between the two isolates of the new species found in Rio Huichihuayán and the one from Río Covadonga. Likewise, the genetic variation between $W$. chavarriae and the new species $(3.3 \%)$ was even higher that that observed for other allocreadiid species pairs (Table 1). For instance, Razo-Mendivil et al. (2014a) obtained 2\% variation of the 28S rRNA gene between two sister species of allocreadiids, Auriculostoma totonacapensis Razo-Mendivil, Mendoza-Garfias, Pérez-Ponce de León et RubioGodoy, 2014 and A. astyanace Scholz, Aguirre-Macedo et Choudhury, 2004. Actually, levels of genetic variation of this molecular marker have been used by several authors to differentiate species of digeneans (e.g. Pérez-Ponce de León et al. 2008, Tkach and Snyder 2008, Blasco-Costa et al. 2009, 2010).

\section{DISCUSSION}

The present study corrects previous reports of allocreadiids from Astayanax mexicanus and enables us to recognise previously undocumented diversity within the Wallinia spp. lineage. The new species we describe herein was originally recorded as two separate species. Pérez-Ponce de León et al. (2010) recorded the macroderoidiid M. simplex as a parasite of $A$. mexicanus in Río Covadonga in the Nazas River Basin, Durango State. Meanwhile, PérezPonce de León et al. (2013) recorded C. aguirrepequenoi with specimens collected from $A$. mexicanus in Río $\mathrm{Hu}-$ ichihuayán, San Luis Potosí, in the Panuco River Basin. Both records were wrong and sequence data obtained recently allowed us to recognise the error, resulting in the description of a new species of Wallinia here. Unfortunately, uncertainty and confusion have surrounded the identification and classification of these digeneans. Choudhury et al. (2002) argued that morphologically, the three species in these three genera are very similar. Additionally, all three species are parasites of the digestive tract of small-bodied characids such as Astyanax spp. and this has also misled previous efforts to identify these digeneans.

The classification of Creptotrematina aguirrepequenoi and Magnivitellinum simplex has also been controversial. 
Table 1. Pairwise distance matrix of $28 \mathrm{~S}$ rRNA gene sequences of two isolates of Wallinia mexicana sp. n. (in bold) from two localities in northern Mexico with respect to other members of the Allocreadiidae.

\begin{tabular}{|c|c|c|c|c|c|c|c|c|c|c|c|c|c|c|c|c|}
\hline & Species & 1 & 2 & 3 & 4 & 5 & 6 & 7 & 8 & 9 & 10 & 11 & 12 & 13 & 14 & 15 \\
\hline 1 & Allocreadium isoporum (Looss, 1984) & - & & & & & & & & & & & & & & \\
\hline 2 & Allocreadium lobatum Wallin, 1909 & 3.4 & - & & & & & & & & & & & & & \\
\hline 3 & $\begin{array}{l}\text { Auriculostoma astyanace Scholz, Aguirre-Macedo et } \\
\text { Choudhury, } 2004\end{array}$ & 7.9 & 6.6 & - & & & & & & & & & & & & \\
\hline 4 & $\begin{array}{l}\text { Auriculostoma totocanapanensis Razo-Mendivil, Mendoza, } \\
\text { Pérez et Rubio-Godoy, } 2014\end{array}$ & 8.7 & 7.1 & 2.1 & - & & & & & & & & & & & \\
\hline 5 & Bunodera sp. & 6.5 & 6.5 & 6.1 & 7.0 & - & & & & & & & & & & \\
\hline 6 & Bunodera lucioperca (Müller, 1776) & 6.6 & 5.3 & 7.3 & 7.3 & 0.8 & - & & & & & & & & & \\
\hline 7 & Crepidostomum cornutum (Osborn, 1903) & 6.6 & 6.0 & 6.4 & 5.0 & 4.9 & 5.0 & - & & & & & & & & \\
\hline 8 & Crepidostomum illinoense Faust, 1918 & 6.6 & 5.9 & 4.2 & 5.2 & 5.0 & 5.1 & 1.8 & - & & & & & & & \\
\hline 9 & Creptotrema funduli Mueller, 1934 & 8.0 & 7.1 & 3.7 & 5.5 & 6.4 & 6.5 & 3.0 & 3.8 & - & & & & & & \\
\hline 10 & Creptotrematina aguirrepequenoi Jiménez-Guzmán, 1973 & 8.1 & 7.2 & 3.7 & 4.4 & 7.3 & 7.2 & 4.3 & 4.6 & 5.4 & - & & & & & \\
\hline 11 & Megalogonia ictaluri Surber, 1928 & 6.8 & 6.2 & 3.0 & 4.4 & 5.3 & 5.4 & 2.6 & 3.0 & 3.1 & 3.9 & - & & & & \\
\hline 12 & $\begin{array}{l}\text { Paracreptotrema heterandriae Salgado-Maldonado, } \\
\text { Caspeta-Mandujano et Vázquez, } 2012\end{array}$ & 7.8 & 7.1 & 3.6 & 4.8 & 6.1 & 6.2 & 3.1 & 3.6 & 4.1 & 3.9 & 4.1 & - & & & \\
\hline 13 & Wallinia chavarriae Choudhury, Hartvigsen et Brooks, 2002 & 8.2 & 7.3 & 4.5 & 4.0 & 6.7 & 6.8 & 3.6 & 4.5 & 4.2 & 3.7 & 3.3 & 3.6 & - & & \\
\hline 14 & Wallinia mexicana sp. n. (Huichihuayán) & 9.0 & 8.0 & 3.6 & 5.0 & 7.4 & 7.4 & 4.2 & 5.1 & 5.0 & 4.4 & 4.2 & 4.1 & 3.3 & - & \\
\hline 15 & Wallinia mexicana sp. n. (Covadonga) & 9.0 & 8.0 & 3.6 & 5.0 & 7.4 & 7.4 & 4.2 & 3.6 & 5.0 & 4.4 & 4.2 & 4.1 & 3.3 & 0.0 & - \\
\hline
\end{tabular}

Yamaguti (1971) placed Magnivitellum simplex and Wallinia valenciae Pearse, 1920 in the Macroderoididae. Later, C. aguirrepequenoi was placed in the Bunoderidae Nicoll, 1914 by Jiménez-Guzmán (1973). This author also found M. simplex and placed it in the Wallinidae Skrjabin et Koval, 1965. Both M. simplex and C. aguirrepequenoi were recorded from Astyanax fasciatus mexicanus $(=A$. mexicanus De Filippi) from the Presa Rodrigo Gómez in Nuevo León, within the Río Bravo (= Grande) basin in northeastern Mexico. Jiménez-Guzmán (1973) discussed the extent of morphological variation in the two species in terms of posterior extension of the vitelline follicles, testes position (oblique, tandem or symmetrical), absence of tegumental spines (in M. simplex) and absence of eye-spots in C. aguirrepequenoi. Thatcher (1993) placed Creptotrematina spp. and M. simplex in the Allocreadiidae Looss, 1902. Choudhury et al. (2002) argued that "as unspined plagiorchiforms with a well-developed cirrus sac, a median genital pore and a tandem arrangement of ovary and testes in the hindbody, Wallinia spp. belonged in Allocreadiidae. However, the oblique placement of the testes, the laterally restricted vitellaria and the manner in which the uterus passes between the testes on its way to an extensive occupation of the post-testicular area in Wallinia spp., M. simplex, and Creptotrematina spp. are all suggestive of macroderoidid affinities." However, recent molecular phylogenetic analyses have unequivocally demonstrated that, at least Wallinia sp. and $C$. aguirrepequenoi, belong to the Allocreadiidae (Pérez-Ponce de León et al. 2007, Curran et al. 2011, RazoMendivil et al. 2014a).
Wallinia mexicana $\mathrm{sp} . \mathrm{n}$. is the third species described in the genus and it was found in the characid A. mexicanus. The Mexican tetra has the most northern distributional range among characids, occurring in northern Mexico and southern U.S.A., in river basins such as the Bravo, Conchos, Nazas, Aguanaval, Mezquital, Tuxpan and Panuco (Miller et al. 2005). Species of Wallinia, like members of the allocreadiid genera Auriculostoma and Creptotrematina are part of the core parasite fauna of characids (see Pérez-Ponce de León and Choudhury 2005) and, as in the case recently described for Auriculostoma by Razo-Mendivil et al. (2014a), it seems that the genus has established a close phylogenetic association with characids in the Neotropical region. These two species appear to be the result of common speciation events that occurred after the isolation of $A$. mexicanus in the river basins of northern Mexico. Further studies where DNA sequences are obtained for isolates in different localities will determine if this is the only species of Wallinia in the Mexican tetra and in other characids in Mexico.

Acknowledgments. We thank the following people for their help during field work: Luis García, Rosario Briosio, Aline Rojas, Rogelio Aguilar, David Hernández and Rogelio Rosas. Thanks are due to Omar Domínguez and Rodolfo Pérez for their help in collecting and identification of fishes. We also thank Luis García, CNHE, Mexico City, for the loan of specimens, and Laura Márquez, for the help with the use of the automated sequencer. This project was supported by grants from PAPIIT-UNAM IN204514 to GPPdL, CONACYT No. 83043 to GPPdL and CB-168306 to MRG. AC wishes to thank St. Norbert College Faculty Development funds for partial support.

\section{REFERENCES}

Aguilar-Aguilar R., Martínez-Aquino A., Pérez-RoDRÍGuez R., PÉrez-Ponce De León G. 2014: Helminth parasites of freshwater fishes from Cuatrociénegas, Coahuila, in the Chihuahuan desert of Mexico: inventory and biogeographical implications. Int. Zool. 9: 328-339.
Blasco-Costa I., Balbuena J.A., Kostadinova A., Olson P.D. 2009: Interrelationships of the Haploporinae (Digenea: Haploporidae): a molecular test of the taxonomic framework based on morphology. Parasitol. Int. 58: 263-269.

Blasco-Costa I., Balbuena J.A., Raga J.A., Kostadinova A., Olson P.D. 2010: Molecules and morphology reveal cryptic 
variation among digeneans infecting sympatric mullets in the Mediterranean. Parasitology 137: 287-302.

Choudhury A., Daverdin R.H., Brooks D.R. 2002: Wallinia chavarriae n. sp. (Trematoda: Macroderoididae) in Astyanax aeneus (Günther, 1860) and Bryconamericus scleroparius (Regan, 1908) (Osteichthyes: Characidae) from the Area de Conservación Guanacaste, Costa Rica. J. Parasitol. 88: 107-112.

Curran S.S., Tkach V.V., Overstreet R.B. 2011: Phylogenetic affinities of Auriculostoma (Digenea: Allocreadiidae), with descriptions of two new species from Peru. J. Parasitol. 97: 661670.

JimÉneZ-GuZmán F. 1973: Tremátodos digéneos de peces dulceacuícolas de Nuevo León, México I: dos nuevas especies y un registro nuevo en el carácido Astyanax fasciatus mexicanus (Filippi). Cuad. Inst. Inv. Cien. UANL., Mex. 17: 1-19

Mendoza-Franco E., Caspeta-Mandujano J.M., SalgadoMaldonado G. 2013: New species of Cacatuocotyle (Monogenoidea, Dactylogyridae) parasitizing the anus and the gill lamellae of Astyanax aeneus (Pisces, Ostariophysi: Characidae) from the Rio Lacantún basin in the Biosphere Reserve of Montes Azules, Chiapas, Mexico. Parasitol. Res. 112: 199-205.

Miller R.R., Minckley W.L., Norris S.M. 2005: Freshwater Fishes of México. The University of Chicago Press, Chicago, Illinois, $652 \mathrm{pp}$.

Mirande J.M. 2010: Phylogeny of the family Characidae (Teleostei: Characiformes): from characters to taxonomy. Neotrop. Ichthyol. 8: 385-568.

Ornelas-García C.P., Domínguez-Domínguez O., Doadrio I. 2008: Evolutionary history of the fish genus Astyanax Baird \& Girard (1854) (Actinopterygii, Characidae) in Mesoamerica reveals multiple morphological homoplasies. BMC Evol. Biol. 8: 340.

Pearse A.S. 1920: The fishes of Lake Valencia, Venezuela. University of Wisconsin Studies in Science 1: 1-51.

Pérez-Ponce de León G., Choudhury A. 2005: Biogeography of helminth parasites of freshwater fishes in México: the search for patterns and processes. J. Biogeogr. 32: 645-659.

Pérez-Ponce de León G., Choudhury A. 2010: Parasite inventories and DNA-based taxonomy: lessons from helminths of freshwater fishes in a megadiverse country. J. Parasitol. 96: $236-244$
Pérez-Ponce de León G., Choudhury A., Rosas-Valdéz R., MejÍA-Madrid H. 2007: Systematic position of Wallinia spp. and Margotrema spp., parasites of Middle-American and Neotropical freshwater fishes based on $28 \mathrm{~S}$ ribosomal RNA gene. Syst. Parasitol. 68: 49-55.

Pérez-Ponce de León G., Mendoza-Garfias B., RosasValdéz R., Choudhury A. 2013: New host and locality records of freshwater fish helminth parasites in river basins north of the Transmexican Volcanic Belt: another look at biogeographical patterns. Rev. Mex. Biodiv. 84: 556-562.

Pérez-Ponce de León G. Razo-Mendivil, U., Rosas-Valdez R., Mendoza-Garfias B. Mejía-Madrid H. 2008: Description of a new species of Crassicutis Manter, 1936, parasite of Cichlasoma beani Jordan (Osteichthyes: Cichlidae) in Mexico, based on morphology and sequences of the ITS1 and 28S ribosomal RNA genes. J. Parasitol. 94: 257-263.

Pérez-Ponce de León G., Rosas-Valdéz R., Aguilar-Aguilar R., Mendoza-Garfias B., Mendoza-Palmero C., García-Prieto L., Rojas A., Briosio-Aguilar R., PérezRodríGuez R., Domínguez-Domínguez, O. 2010: Helminth parasites of freshwater fishes in the Nazas River Basin, northern Mexico. Check List 6: 26-35.

Razo-Mendivil U., Mendoza-Garfias B., Pérez-Ponce de León G., Rubio-Godoy, M. 2014a: A new species of Auriculostoma (Digenea: Allocreadiidae) in the Mexican tetra Astyanax mexicanus (Actinopterygii, Characidae) from central Veracruz, Mexico, described using morphological and molecular data. J. Parasitol. 100: 331-337.

Razo-Mendivil U., Mendoza-Garfias B., Pérez-Ponce de LeÓN G., Rubio-Godoy, M. 2014b: Testing the systematic position and relationships of Paracreptotrema heterandriae within the Allocreadiidae through partial 28s rRNA gene sequences. J. Parasitol. 100: 537-541.

Thatcher, V.E. 1993: Trematódeos Neotropicais. INPA/FUA, Manaus, Brazil, 553 pp.

Tкасн, V., SNyder S.D. 2008: Aptorchis glandularis n. sp. (Digenea: Plagiorchoidea) from the northwestern red-faced turtle, Emydura australis (Pleudodira: Chelidae) in the Kimberley, western Australia. J. Parasitol. 94: 918-924.

Yamaguti, S. 1971: Synopsis of Digenetic Trematodes of Vertebrates. Vol. I. Keigaku Publishers, Tokyo, 1074 pp.

Cite this article as: Pérez-Ponce de León G., Razo-Mendivil U., Mendoza-Garfias B., Rubio-Godoy M., Choudhury A. 2015: A new species of Wallinia Pearse, 1920 (Digenea: Allocreadiidae) in Astyanax mexicanus (Characidae) from Mexico revealed by morphology and sequences of the 28S ribosomal RNA gene. Folia Parasitol. 62: 018. 